\title{
Studi Pemetaan Persebaran Sedimen Boezem Morokrembangan
}

\author{
Rahmah Fitrianingtyas dan Agus Slamet \\ Departemen Teknik Lingkungan , Fakultas Teknik Sipil, Lingkungan dan Kebumian, Institut \\ Teknologi Sepuluh Nopember (ITS) \\ e-mail: agus.tlits@gmail.com
}

\begin{abstract}
Abstrak-Boezem Morokrembangan Sisi Selatan merupakan salah satu retention basin atau embung pengendali banjir di Kota Surabaya yang memiliki 2 inlet saluran drainase yaitu Kali Greges dan Kali Purwodadi. Kedua saluran tersebut merupakan badan air kelas IV menurut PP No.82/2001 yang tertuang dalam PERDA Kota Surabaya No. 02 Tahun 2004. Penelitian dilakukan 2 tahap yaitu observasi di lapangan dan analisis pemetaan persebaran sedimen dengan Surfer 10. Hasil penelitian ini didapatkan laju akumulasi lumpur berdasarkan pengukuran dengan metode Imhoff cone pada air Boezem Morokrembangan sisi selatan adalah 11010,30 sampai $12653,64 \mathrm{~m}^{3} /$ tahun dan dengan metode mass balance adalah 4481,22 sampai 5150,04 $\mathrm{m}^{3} /$ tahun. Dari peta persebaran atau isokonsentrasi total suspended solid menggunakan Surfer 10 menunjukkan perubahan yang dinamis yaitu terjadi penurunan dari inlet menuju tengah Boezem dan meningkat menuju ke outlet. Kondisi tersebut disebabkan oleh adanya pengerukan dan pertumbuhan alga. Pada tepi Boezem juga menunjukkan adanya dead zone yang disebabkan oleh aliran air rendah dan adanya alga pada perairan. Rekomendasi penanganan pengendapan sedimen atau lumpur di Boezem Morokrembangan dapat menggunakan barrier dan menggunakan eceng gondok (Eichornia crassipes).
\end{abstract}

Kata Kunci-Akumulasi Lumpur, Boezem Morokrembangan, Pemetaan Sedimen, Surfer 10.

\section{PENDAHULUAN}

$\mathrm{B}$ OEZEM Morokrembangan merupakan salah satu Boezem terbesar di Surabaya. Boezem merupakan muara dari saluran drainase Surabaya yang juga memiliki fungsi sebagai pengendali banjir. Saat ini, Boezem mengalami pendangkalan yang diakibatkan oleh tingginya air limbah domestik yang di salurkan ke Boezem bersama dengan air drainase. Hal tersebut mengakibatkan Boezem Morokrembangan memiliki air yang berwarna hitam.

Boezem Morokrembangan ini memiliki daerah tangkapan 25\% dari luas wilayah Surabaya dengan input yaitu Kali Greges, Kali Purwodadi dan Kali Pesapen. Kedua sungai tersebut telah ditetapkan menjadi Badan Air Kelas IV PP No.82/2001 yang tertuang dalam PERDA Kota Surabaya No. 02 Tahun 2004. Sebagian besar air yang masuk kedalam Boezem merupakan air yang berasal dari air limbah domestik. Berdasarkan karakteristik air limbah pada umumnya, air limbah ini mengandung bahan organik yang tinggi. Hal tersebut sesuai dengan hasil COD pada Kali Greges, Kali Purwodadi dan outlet Boezem Morokrembangan yaitu 75,0 $\mathrm{mg} / \mathrm{L}, 48,232 \mathrm{mg} / \mathrm{L}$ dan $45,137 \mathrm{mg} / \mathrm{L}$ [1]. Nilai COD tersebut telah melampaui baku mutu menurut Perda Kota Surabaya No.
02 Tahun 2004 dengan batas COD yang diijinkan dalam 50 $\mathrm{mg} / \mathrm{L}$. Boezem Morokrembangan memiliki self purification dalam menurunkan beban organik yang masuk kedalam boezem. Pemurnian alami pada suatu badan air diindikasikan dengan adanya penurunan konsentrasi badan pencemar dari sumber menuju outlet itu sendiri [2].

Pertambahan penduduk kota Surabaya akan meningkatkan produksi air limbah sehingga jumlah sedimentasi di dalam Boezem Morokrembangan pun juga meningkat. Kadar COD, TS dan TSS yang masuk ke Boezem Morokrembangan bagian selatan saat musim kemarau adalah 44,97 ton/hari, 233,815 ton/hari, dan 9,375 ton/hari [3]. Saat musim hujan kadar COD, TS, dan TSS mengalami peningkatan yaitu 115,17 ton/hari, 444,875 ton/hari, dan 24,98 ton/hari.Kondisi air di Boezem Morokrembangan pada saat ini terutama sisi selatan sangat berbau dan bewarna hitam. Kondisi ini diakibatkan oleh pengendapan sedimen yang berasal dari air limbah domestik dari catchment area Boezem Morokrembangan. Sedimentasi yang berasal dari alga atau partikel diskrit akan mendangkalkan Boezem dan mempengaruhi penurunan kadar air limbah [4]. Dalam jangka panjang, efisiensi kerja Boezem dipengaruhi oleh akumulasi lumpur yang mengurangi volume efektif [5]. Hal tersebut karena berkuranganya kapasitas tampung air akibat adanya sedimentasi dalam Boezem [6] Bahan-bahan pencemar dalam sumber-sumber air yang terlarut dalam partikel tersuspensi juga akan membahayakan ekosistem badan air [7].

Pengerukan yang dilakukan eksisting tidak dilakukan secara periodik [8]. Hal tersebut disebabkan oleh sedimen yang masuk ke dalam Boezem Morokrembangan tersebar merata ke seluruh area Boezem. Dalam penelitian ini akan dilakukan perhitungan laju akumulasi lumpur yang masuk ke dalam Boezem Morokrembangan dan pemetaan sedimen yang terdapat pada Boezem Morokrembangan sisi Selatan. Pemetaan sedimen yang dilakukan mengunakan Surfer 10.

\section{URAIAN PENELITIAN}

\section{A. Ide Penelitian}

Ide tugas akhir ini berasal dari kondisi eksisting Boezem Morokrembangan sisi Selatan yaitu terjadi pendangkalan akibat adanya sedimen atau padatan. Keadaan ini secara langsung mempengaruhi Boezem Morokrembangan Sisi Selatan yaitu penurunan daya tampung di Boezem tersebut. Menurut PP No 38 Tahun 2001 pengelolan atau perlindungan 
Boezem atau waduk harus dilakukan guna mempertahankan volume tambungannya sebesar $95 \%$. Berdasarkan hal tersebut, sedimen yang dihasilkan juga menyebar ke segala sisi Boezem Morokrembangan diperlukan perhitungan akumulasi lumpur dan pemetaan sedimen untuk mengetahui persebaran sedimen yang berada pada Boezem Mororkrembangan sisi selatan

\section{B. Studi Literatur}

Studi literatur dilakukan dengan mencari artikel-artikel yang menunjang penelitian dari sumber-sumber yang ada (textbook, jurnal penelitian, internet, dan sebagainya). Datadata tersebut dapat berupa pustaka tentang karakteristik air limbah, karakteristik lumpur, pengendapan lumpur, akumulasi lumpur, dan proses penurunan beban pencemar.

\section{Pengumpulan Data}

Data dalam penelitian ini dibagi menjadi dua yaitu data primer dan data sekunder. Data primer didapatkan berdasarkan analisa laboratorium dan pengukuran secara langsung di lapangan. Data sekunder didaptkan dari dinas terkait seperti Dinas PU Bina Marga dan Pematusan Kota Surabaya dan Balai Besar Wilayah Sungai Brantas.

\section{Pelaksanaan Penelitian}

Penelitian ini menggunakan analisis Total solid, Total suspended solid, pola aliran, dan akumulasi lumpur. Penentuan lokasi sampling untuk analisa laju akumulasi lumpur yaitu 2 titik pada inlet Boezem yaitu Kali Greges dan Kali Purwodadi dan outlet Boezem Morokrembangan sisi Selatan.

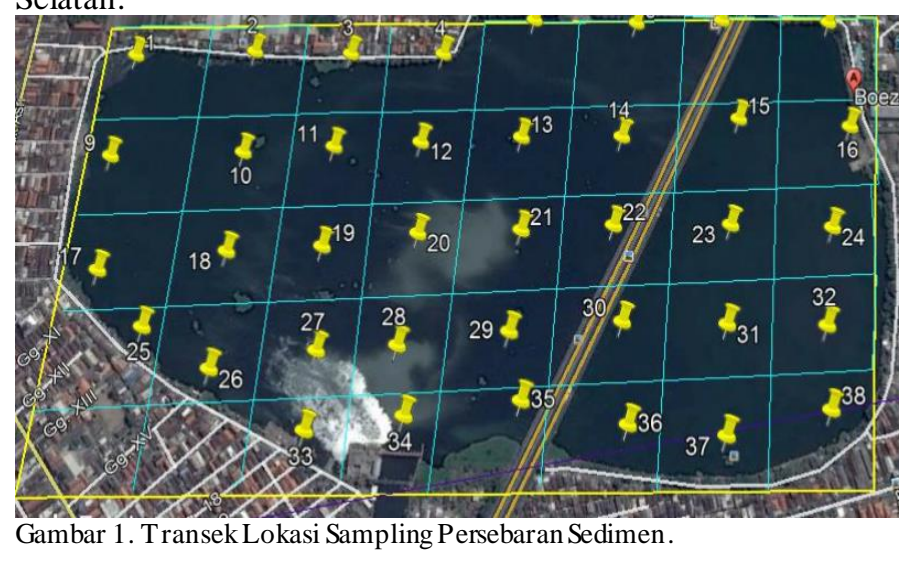

Waktu yang digunakan dalam pengambilan air sampel analisis Total solid, Total suspended solid, dan akumulasi lumpur adalah 3 kali sehari selam 7 hari berturut-turut. Rincian waktu yang digunakan dalam pengambilan sampel yaitu pada pagi hari sekitar pukul 08.00, siang hari sekitar pukul 12.00, dan sore sekitar pukul 16.00 WIB. Hal tersebut dilakukan untuk mengantisipasi adanya debit yang fluktuatif. Lokasi sampling untuk pemetaan persebaran sedimen dilakukan dengan menggunakan transek $100 \mathrm{~m}$ x $100 \mathrm{~m}$, dengan titik-titik lokasi yang dapat dilihat pada Gambar 1 Waktu pengambilan sampel untuk persebaran sedimen dilakukan 2 hari 1 kali selama 3 kali berturut-turut.

\section{HASIL DAN PEMBAHASAN}

\section{A. Pengukuran Debit}

Pengukuran debit ini berdasarkan SNI 80662015 dengan mengunakan alat pelampung. Alat tersebut digunakan untuk mengetahui kecepatan aliran pada saluran. Hasil dari pengukuran debit tiap saluran dapat dilihat pada Gambar 3. Dari Gambar 3 dapat diketahui bahwa debit air pada Kali Purwodadi, Kali Greges dan Outlet mengalami fluktuatif dan tidak beraturan. Debit yang masuk ke Kali Greges dan Kali Purwodadi dipengaruhi oleh banyaknya sampah yang terbawa oleh aliran air, semakin sedikit sampah yang diangkut pada aliran akan mempercepat kecepatan aliran air [9].

Debit rata-rata tiap hari pada inlet Kali Purwodadi, Kali Greges dan Outlet Boezem Morokrembangan Sisi Selatan didapatkan $0,21 \mathrm{~m}^{3} / \mathrm{s}, 2,3 \mathrm{~m}^{3} / \mathrm{s}$, dan $2,14 \mathrm{~m}^{3} / \mathrm{s}$. Debit hasil pengukuran pada dua saluran yaitu inlet Kali Purwodadi dan inlet Kali Greges lebih besar dibandingkan outlet. Hal itu disebabkan terjadinya evaporasi (transpirasi) dan infiltrasi dalam tanah. Evaporasi (transpirasi) adalah air yang berada dala Boezem menguap ke atmosfer dan kemudian akan menjadi awan dan infiltrasi dalam tanah merupakan pergerakan air yang memasuki pori-pori tanah dan batuan karena aksi kapiler [10].

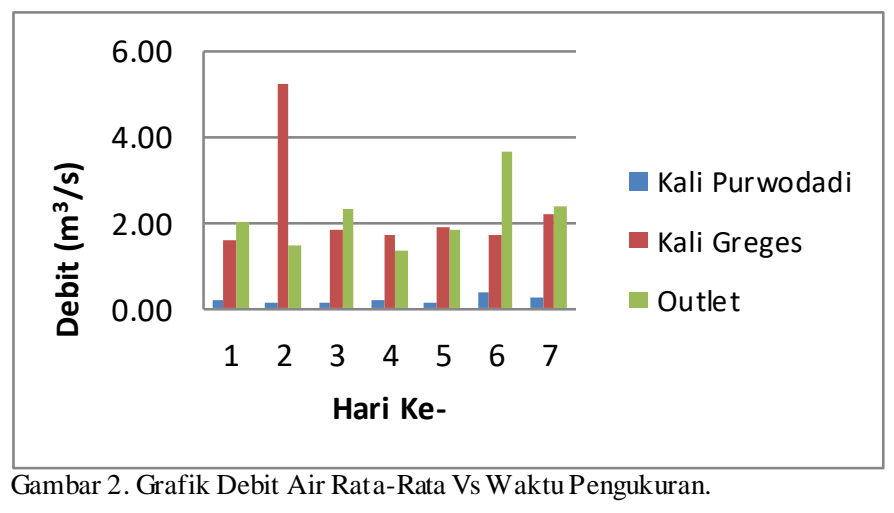

\section{B. Akumulasi Lumpur}

Dalam perhitungan akumulasi lumpur dilakukan perhitungan beban dari konsentrasi total solid pada masingmasing saluran dan persentase pengendapan yang terjadi.

Beban awal = Beban TS Inlet Kali Greges Awal + Beban TS Inlet Kali Purwodadi Awal $=10635,6 \mathrm{~kg} / \mathrm{jam}+701,8 \mathrm{~kg} / \mathrm{jam}$ $=11337,4 \mathrm{~kg} / \mathrm{jam}$

Beban akhir = Beban TS Inlet Kali Greges Akhir + Beban TS Inlet Kali Purwodadi Akhir $=8836,2 \mathrm{~kg} / \mathrm{jam}+538,48 \mathrm{~kg} / \mathrm{jam}$ $=9374,68 \mathrm{~kg} / \mathrm{jam}$

$$
\begin{aligned}
\% R & =\frac{(\text { Beban awal-Beban Akhir })}{\text { Beban Awal }} \times 100 \% \\
\% R & =\frac{(11337,4-9374,68)}{11343,67} \times 100 \% \\
\% \mathrm{R} & =17,3 \%
\end{aligned}
$$




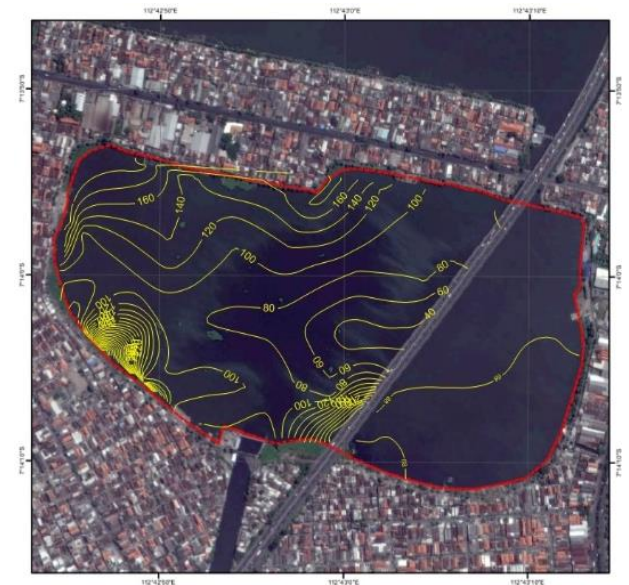

Gambar 3 Persebaran/Isokonsentrasi Total Suspended Solid 11 Sept ember 2017.

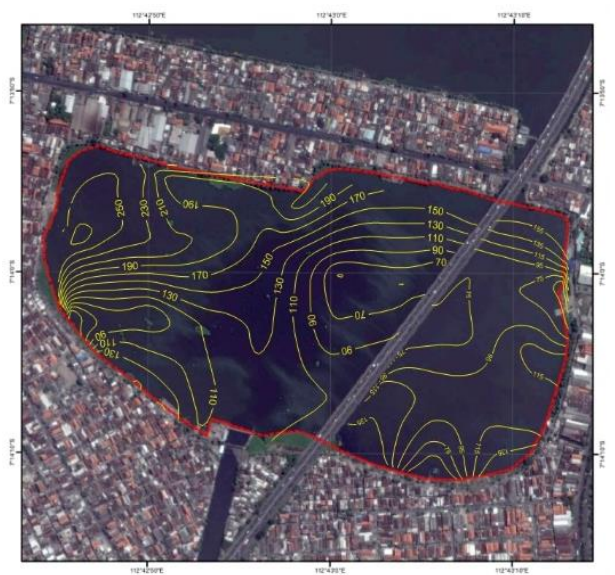

Gambar 4. Persebaran/Isokonsentrasi Total Suspended Solid 13 Sep t ember 2017.

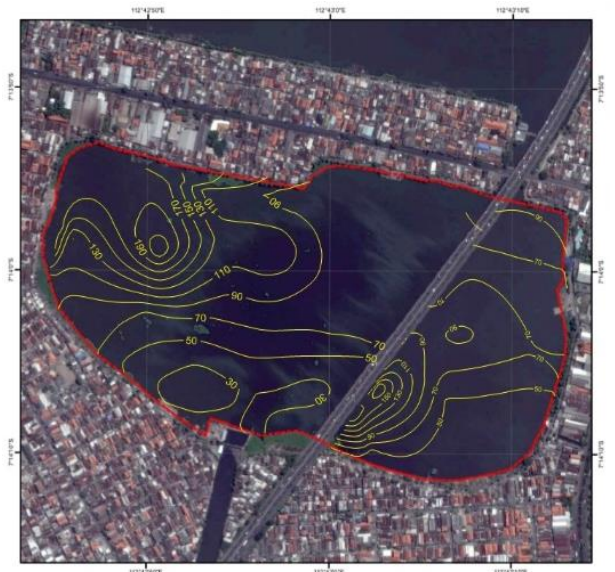

Gambar 5 Persebaran/Isokonsentrasi Total Suspended Solid 15 Se ptember 2017.

Dari perhitungan di atas didapatkan persentase pengendapan sedimen (total solid) adalah 17,3\%. Hal itu berarti $17,3 \%$ dari konsentrasi total solid yang akan mengendap pada Boezem Morokrembangan Sisi Selatan. Akumulasi lumpur atau padatan umumnya sebanding dengan kecepatan arus [11]. Akumulasi lumpur dapat dihitung dengan persamaan sebagai berikut.

[Akumulasi $]=[$ input $]-[$ penurunan karena reaksi $]-[$ out $](2)$ Akumulasi $=\%$ R Beban TS Kali Purwodadi $=17,3 \% 701,8 \mathrm{~kg} / \mathrm{jam}=2,9$ ton $/$ hari
Akumulasi $=\%$ R Beban TS Kali Greges

$=17,3 \% 10635,6 \mathrm{~kg} / \mathrm{jam}=44,18$ ton $/$ hari

Akumulasi Bruto $=2,9$ ton $/$ hari $+44,18$ ton $/$ hari $=47,1$ ton $/$ hari

Proses biodegradasi lumpur didapatkan regresi yang mendekati 1 adalah dengan menggunakan reaksi orde satu dengan persamaan $\mathrm{y}=-0,018 \mathrm{x}-0,0313$ [12], sehingga dilakukan perhitungan sebagaiberikut.

$$
\begin{aligned}
& \text { Co }=\frac{\text { Beban TS awal Kali Purwodadi }+ \text { Beban TS awal Greges }}{\text { Q Greges }+ \text { Q Purwodadi }} \\
& \text { Co }=\frac{197820 \frac{\mathrm{mg}}{\text { detik }}+4763640 \frac{\mathrm{mg}}{\text { detik }}}{3,71 \frac{\mathrm{m}^{3}}{\text { detik }^{3}}+0,21 \frac{\mathrm{m}^{3}}{\text { detik }^{2}}} \\
& \text { Co }=1255,38 \mathrm{mg} / \mathrm{L} \\
& \mathrm{C}=\% \mathrm{R} \text { Co } \\
& \mathrm{C}=17,3 \% 1255,38=217,18 \mathrm{mg} / \mathrm{L}
\end{aligned}
$$

Dari perhitungan di atas didapatkan konsentrasi sedimen yang mengendap adalah 217,18 mg/L, kemudian dilakukan perhitungan konsentrasi akhir (Ct) lumpur yang berkurang akibat adanya biodegradasi sebagai berikut.

$$
\mathrm{Ct}=\mathrm{Ce}^{-\mathrm{kt}}
$$

$\mathrm{Ct}=217,18 \mathrm{mg} / \mathrm{L} \mathrm{e}^{-0,018 \times 1}=213,3 \mathrm{mg} / \mathrm{L}$

Sehingga $\mathrm{kC}=\mathrm{C}-\mathrm{Ct}$

$$
=217,18-213,3=3,9 \mathrm{mg} / \mathrm{L}
$$

Dari perhitungan di atas didapatkan penurunan akibat biodegradasi adalah 3,9 mg/L. Kemudian dihitung volume lumpur yang masuk dan terendapkan dalam Boezem Morokrembangan sisi selatan perharinya. Volume lumpur yang terendapkan didapatkan melalui analisa Imhoff cone dengan memasukkan air sampel sejumlah 1 liter dan diendapkan selama 30 menit. Volume rata-rata lumpur yang terendapkan pada Kali Purwodadi dan Kali Greges adalah 0,63 $\mathrm{mL} / \mathrm{L}$ dan $0,46 \mathrm{~mL} / \mathrm{L}$ dan dihitung volume sedimen yang mengendap pada Boezem Morokrembangan sisi selatan sebagaiberikut.

$$
\begin{gathered}
V=\frac{\text { Vpurwodadi Qpurwodadi }+ \text { Vgreges Qgreges }}{\text { Qpurwodadi }+ \text { Qgreges }} \\
\mathrm{V}=\frac{0,63 \frac{\mathrm{mL}}{\mathrm{L}} 210 \frac{\mathrm{L}}{\text { detik }}+0,46 \frac{\mathrm{mL}}{\mathrm{L}} 2300 \frac{\mathrm{L}}{\text { detik }}}{210 \frac{\mathrm{L}}{\text { detik }}+2300 \frac{\mathrm{L}}{\text { detik }}} \\
\mathrm{V}=0,47 \mathrm{~mL} / \mathrm{L}
\end{gathered}
$$

$$
\begin{aligned}
\text { Akumulasi } & =\text { Akumulasi Bruto }- \text { Penurunan karena } \\
& \text { reaksi }- \text { out } \\
& =47,1 \text { ton } / \text { hari }-[\mathrm{kC} . \mathrm{V}]-\text { out } \\
& =47,1 \text { ton } / \text { hari }-\left[3,9 \mathrm{mg} / \mathrm{L} 0,4710^{-3} \mathrm{~L} / \mathrm{L}\right. \\
& 216864000 \mathrm{~L} / \mathrm{hari}] \\
& =47,1 \mathrm{ton} / \mathrm{hari}-0,0003975 \mathrm{ton} / \mathrm{hari} \\
& =47,09 \text { ton } / \mathrm{hari} \\
& =1412,99 \text { ton } / \text { bulan }
\end{aligned}
$$

Akumulasi total lumpur yang terendapkan pada Boezem Morokrembangan sisi selatan adalah 1412,99 ton/bulan. Untuk mencari volume Boezem Morokrembangan sisi selatan yang berkurang akibat akumulasi lumpur dengan cara membagi akumulasi total lumpur dengan densitas lumpur. Densitas lumpur 1,34 sampai $1,54 \mathrm{~g} / \mathrm{cm}^{3}$ [8]. 


$$
\begin{aligned}
V & =\frac{m}{\rho} \\
V & =\frac{1412,99 \frac{\text { ton }}{\text { bulan }}}{1340 \text { sampai } 1540 \frac{\mathrm{kg}}{\mathrm{m} 3}} \\
\mathrm{~V} & =917,52 \text { sampai } 1054,47 \mathrm{~m}^{3} / \mathrm{bulan} \\
\mathrm{V} & =11010,3 \text { sampai } 12653,64 \mathrm{~m}^{3} / \text { tahun }
\end{aligned}
$$

Akumulasi lumpur yang terjadi dengan pendekatan mass balance digunakan konsentrasi total solid awal (Co) dan akhir (Ce) dan beban total solid awal (B) dan akhir (Be) didapatkan berdasarkan pengukuran lapangan yaitu 1255,38 mg/L, 1364 $\mathrm{mg} / \mathrm{L}, \quad 11337,4 \mathrm{~kg} / \mathrm{jam}$ dan $10533 \mathrm{~kg} / \mathrm{jam}$. Kemudian dilakukan perhitungan persentase pengendapan sebagai berikut.

$$
\begin{aligned}
& \% R=\frac{(11337,4-10533)}{11337,4} \times 100 \% \\
& \% \mathrm{R}=7,09 \\
& \mathrm{C}=\% \mathrm{R} \mathrm{Co} \\
& \mathrm{C}=7,09 \% 1255,38 \\
& \mathrm{C}=88,97 \mathrm{mg} / \mathrm{L} \\
& \mathrm{Ct}=\mathrm{C} \mathrm{e}^{-\mathrm{kt}} \\
& \mathrm{Ct}=88,97 \mathrm{mg} / \mathrm{L} \mathrm{e}^{-0,018 \times 1} \\
& \mathrm{Ct}=87,38 \mathrm{mg} / \mathrm{L} \\
& \mathrm{Sehingga} \mathrm{kC}=\mathrm{C}-\mathrm{Ct} \\
& \quad=88,97-87,38=1,58 \mathrm{mg} / \mathrm{L}
\end{aligned}
$$

Volume rata-rata lumpur yang terendapkan pada outlet adalah adalah $0,38 \mathrm{~mL} / \mathrm{L}$ dan dihitung volume sedimen yang mengendap pada Boezem Morokrembangan sisi selatan sebagaiberikut.

$$
\mathrm{V}=\frac{0,38 \frac{\mathrm{mL}}{\mathrm{L}} 2140 \frac{\mathrm{L}}{\operatorname{detik}}}{2140 \frac{\mathrm{L}}{\operatorname{detik}}}
$$$$
\mathrm{V}=0,38 \mathrm{~mL} / \mathrm{L}
$$

Akumulasi Bruto $=7,09 \%$ Beban Awal

$$
=19,296 \text { ton } / \text { hari }
$$

Akumulasi $=$ Akumulasi Bruto - Penurunan karena reaksi

$=$ Beban in - Beban out $-[\mathrm{kC}$. V]

$=272,1$ ton $/$ hari $-252,8$ ton $/$ hari $-[1,58 \mathrm{mg} / \mathrm{L}$

$\left.0,3810^{-3} \mathrm{~L} / \mathrm{L} 216864000 \mathrm{~L} / \mathrm{hari}\right]$

$=19,16$ ton $/$ hari

$=575,09$ ton/bulan

$V=\frac{m}{\rho}$

$\mathrm{V}=\frac{575,09 \frac{\text { ton }}{\text { bulan }}}{1340 \text { sampai } 1540 \frac{\mathrm{kg}}{\mathrm{m}^{3}}}$

$\mathrm{V}=373,135$ sampai $429,17 \mathrm{~m}^{3} /$ bulan

$\mathrm{V}=4481,22$ sampai $5150,04 \mathrm{~m}^{3} /$ tahun

Berdasarkan perhitungan di atas, didapatkan akumulasi total lumpur dengan menggunakan mass balance pada Boezem Morokrembangan sisi selatan adalah 4481,22 sampai
$5150,04 \mathrm{~m}^{3} /$ tahun. Hasil tersebut lebih kecil dibandingkan dengan perhitungan menggunakan metode Imhoff cone yaitu 11010,3 sampai 12653,64 $\mathrm{m}^{3} /$ tahun. Hal tersebut dapat terjadi karena pada metode Imhoff cone tidak terjadi aliran masuk dan keluar sehingga pengendapan yang dilakukan maksimal. Disamping itu, pada kondisi eksisting dilakukan pengerukan sedimen/lumpur setiap hari sehingga menimbulkan terjadinya turbulensi pada aliran air dan sedimen yang telah mengendap. Adanya konsentrasi tinggi $\mathrm{N}$ dan $\mathrm{P}$ pada Boezem Morokrembangan juga akan memicu pertumbuhan alga pada perairan.

\section{Persebaran Sedimen}

Persebaran sedimen dapat dilihat dengan penurunan dan peningkatan konsentrasi total suspended solid pada air [13]. Pada inlet Kali Greges terjadi pengendapan yang tinggi sehingga menimbulkan bukit yang berbetuk setengah lingkaran pada garis isokonsentrasi. Hal tersebut menunjukkan adanya konsentrasi yang tinggi pada air dan adanya tumpukan atau delta sedimen pada daerah tersebut. Semakin jauh dari inlet konsentrasi total suspended solid semakin menurun dan akan meningkat lagi. Pada inlet kali Purwodadi didapatkan konsentrasi yang relatif sama tiap daerah pengamatan. Hal tersebut dapat ditunjukkan pada Gambar 3.

Pada pengamatan yang kedua didapatkan hal yang sama dengan pengamatan pada hari pertama. Pada belokan dan daerah ujung-ujung Boezem Morokrembangan Sisi Selatan terdapat konsentrasi yang tinggi pada Gambar 4. Hal tersebut mengindikasikan adanya dead zone. Dead zone terbentuk karena adanya aliran yang rendah (tenang) sehingga timbul adanya alga. Hal tersebut menyebabkan isokonsentrasi pada daerah pinggir Boezem tinggi. Pada inlet Kali Purwodadi menunjukkan adanya endapan di dekat inlet. Konsentrasi total suspended solid akan menurun pada tengah boezem dan akan meningkat seiring dengan meningkatnya jarak dengan inlet.

Adanya dua daerah tumpukan sedimen yaitu daerah di dekat inlet dan daerah pinggir Boezem pada Gambar 3. Konsentrasi akan menurun pada tengah boezem dan akan meningkat seiring dengan meningkatnya jarak dengan in let. Pergerakan sedimen dipengaruhi oleh bentuk, ukuran dan specific gravity yang dipengaruhi oleh kecepatan dan turbulensi aliran [8]. Konsentrasi pada Gambar 5 dari tengah Boezem sampai ke outlet memiliki konsentrasi yang sama. Hal tersebut dapat terjadi dikarenakan oleh bentuk partikel sedimen yang sulit mengendap yaitu partikel flok dan lumpur biologis. Dari hal tersebut akan menyebabkan timbulnya Bulking sludge atau lumpur yang sulit mengendap, sehingga konsentrasi dari tengah Boezem sampai ke outlet menujukkan konsentrasiyang sama.

Penurunan total suspended solid tersebut menunjukkan bahwa partikel sedimen yang memiliki diameter besar dan kecepatan sedimentasi tinggi akan mengendap terlebih dahulu. Hal tersebut sesuai dengan [14] bahwa pengendapan sedimen umumnya bermulanya pengendapan sedimen kasar di daerah hulu reservoir. Peningkatan konsentrasi sedimen tersebut dapat terjadi karena adanya kandungan $\mathrm{N}$ dan $\mathrm{P}$ yang tinggi pada Boezem sehingga menimbulkan tumbuhnya alga dan ganggang pada Boezem. Hal tersebut dibuktikan pada 
penelitian yang pernah dilakukan oleh [1] bahwa konsentrasi N-organik dan P-total pada inlet Kali Greges, inlet Kali Purwodadi dan Outlet Boezem Morokrembangan adalah $18,773 \mathrm{mg} / \mathrm{L}, 18,038 \mathrm{mg} / \mathrm{L}$, dan $16,668 \mathrm{mg} / \mathrm{L}$ serta untuk konsentrasi P-total yaitu $0,069 \mathrm{mg} / \mathrm{L}, 0,071 \mathrm{mg} / \mathrm{L}$ dan 0,041 $\mathrm{mg} / \mathrm{L}$. Konsentrasi P-total merupakan jumlah total fosfat baik partikulat maupun terlarut. Fosfat terlarut terdiri dari fosfat anorganik fan fosfat organik berupa orthofosfat dan polifosfat [15]. Fosfor diserap oleh alga dalam bentuk ortofosfat. Nitrogen organik terdiri dari protein dan urea [16]. Nitrogen akan diserap oleh alga dalam bentuk nitrat [17]. N-organik akan dioksidasi oleh bakteri untuk menjadi nitrogen organik (nitrat dan ammonia) kemudian akan diserap oleh alga.

Nitrogen dan fosfat dibutuhkan oleh seluruh jaringan makhluk hidup, seperti untuk fotosintesis dan respirasi Kandung nitrat lebih besar $10 \mathrm{mg} / \mathrm{l}$ dapat menyebakan pertumbuhan yang pesat dari alga (blooming algae) [18]. Karbon, nitrogen dan fosfor merupakan faktor lingkungan utama yang harus tersedia dalam pertumbuhan alga [19]. Dalam pengukuran total suspended solid alga atau ganggang tidak dapat dipisahkan dengan jumlah padatannya (lumpur). Oleh karena itu adanya alga atau ganggang dapat meningkatkan konsentrasi total suspended solid dalam perairan.

Kondisi eksisting, kegiatan pengerukan setiap hari berpengaruh pada konsentrasi total suspended solid. Hal tersebut dikarenakan terjadinya turbulensi pada air sehingga dapat meningkatkan konsentrasi total suspended solid. Total suspended solid dipengaruhi oleh adukan/turbulensi yang diakibatkan oleh kedinamisan kondisi perairan [20]. Berdasarkan analisis dapat diketahui bahwa persebaran sedimen pada Boezem Morokrembangan menunjukkan penurunan dari inlet dan meningkat menuju ke outlet. Kondisi tersebut disebabkan oleh adanya pengerukan yang menyebabkan resuspensi sedimen yang telah mengendap dan adanya alga. Pada tepi Boezem juga menunjukkan adanya dead zone yang disebabkan oleh aliran air rendah dan adanya alga pada perairan.

\section{Rekomendasi Penanganan Sedimen}

Eceng gondok (Eichornia crassipes) merupakan salah satu tumbuhan air (gulma) yang ditemukan di Boezem Morokrembangan. Eceng gondok memiliki akar serabut yang dapat mengumpulkan dan mengurangi kadar Total suspended solid dalam perairan tercemar [21]. Rasio BOD dan COD dari inlet Kali Greges dan Kali Purwodadi memiliki nilai mendekati 0,5 [22]. Hal tersebut menunjukkan bahwa hampir $50 \%$ air limbah domestik yang masuk ke dalam Boezem merupakan biodegradable dan belum terolah.

Eceng Gondok yang diberikan air limbah dengan waktu 2 hari, 4 hari dan 6 hari memiliki efisiensi removal Total Suspended Solid (TSS) yaitu 37\%, 61\%, 79\% [22]. Keunggulan dari eceng gondok adalah dapat menyerap senyawa nitrogen dan fosfor dari air yang tercemar dan berpotensi untuk digunakan sebagai komponen utama pembersih air limbah dari berbagai industri dan rumah tangga [23]. Mekanisme dari penurunan TSS tersebut adalah eceng gondok memiliki kemampuan mempercepat evapotranspirasi sehingga dapat mengurangi kadar air di dalam air limbah. Evapotranspirasi tersebut juga mendukung laju pengambilan unsur hara yang dibutuhkan dalam proses fotosintesis melalui bulu-bulu akarnya. Penyerapan unsur hara yang dilakukan merupakan simbiosis akar tanaman dengan mikroba rhizosfer, dimana akan terjadi penguraian zat-zat organik yang terdapat dalam air limbah [24]. Dengan demikian zat-zat organik yang berupa sedimen akan menempel pada akar dari eceng gondok.

Berdasarkan Rekomendasi Teknologi Kelautan dan Perikanan yang diterbitkan oleh Kementrian Kelautan dan Perikanan [25], eceng gondok merupakan teknologi pengendalian secara fisik dan biologis. Eceng gondok dapat dimanfaatkan untuk mengurangi kadar polutan seperti TSS, COD, dan lainnya. Penanganan air limbah domestik dengan eceng gondok ini tentunya juga harus dilakukan pengendalian berupa pemanenan eceng gondok secara periodik. Kisaran perkembangan eceng gondok yaitu 11-18 hari atau memiliki pertumbuhan berkisar 7,1 sampai $10 \%$ setiap bulannya [26].

Masing-masing bagian dalam eceng gondok ini dapat dimanfaatkan, antara lain batang dapat digunakan untuk industri kreatif sebagai kerajinan. Daun eceng gondok dapat digunakan untuk pakan ikan pada budidaya Ikan Koan dan akar eceng gondok yang dapat digunakan untuk kompos atau biogas. Sehingga teknologi menggunakan eceng gondok ini juga dapat mendukung pembangunan berkelanjutan (suistanable development) yaitu mengoptimalkan manfaat dari sumber daya alam dan sumber daya manusia dengan menyerasikan sumber alam dan manusia dalam pembangunan. Penggunaan teknologi dengan menggunakan eceng gondokini juga harus dilengkapi dengan barier atau pembatas pada bagian sisi sampingnya. Hal tersebut bertujuan agar pertumbuhan eceng gondok dapat dikendalikan dan dikelola dengan baik sehingga tidak menyebar luas di seluruh permukaan perairan. Pada Boezem Morokrembangan, rekomendasi ini dapat diterapkan pada lokasi Boezem tertentu yang memiliki konsentrasi total suspended solid yang tinggi.

\section{KESIMPULAN}

Kesimpulan dalam penelitian adalah sebagaiberikut :

1. Laju akumulasi lumpur berdasarkan pengukuran dengan metode Imhoff cone pada air Boezem Morokrembangan sisi selatan sebesar (11010,3 sampai $12653,64) \mathrm{m}^{3} /$ tahun sedangkan analisis dengan neraca massa sebesar $(4481,22$ sampai 5150,04$) \mathrm{m}^{3} / \mathrm{tahun}$.

2. Konsentrasi Total Suspended Solid mengalami perubahan dinamis yaitu terjadi penurunan dari zona inlet ke bagian zona tengah Boezem dan selanjutnya terjadi kenaikan konsentrasi yang disebabkan kemungkinan pertumbuhan alga.

3. Pertumbuhan alga terjadi pada deadzone yang berada pada beberapa bagian pada tepi Boezem.

\section{UCAPAN TERIMA KASIH}

Penulis R.F mengucapkan terima kasih kepada Dinas PU Bina Marga dan Pematusan Surabaya dan Balai Besar Wilayah Sungai Brantas yang telah membantu dalam pemberian data sekunder dan memberikan perijinan untuk melakukan studidi lokasi. 


\section{DAFTAR PUSTAKA}

[1] A. Hananta, "Studi Kinerja Boezem Morokrembangan pada Penurunan Kandungan Nitrogen Organik dan Fosfat Total," Surabaya, 2010.

[2] I. Ifabiyi, "Self Purification of a Freshwater Stream in Ife-Ife: Lessons for Wastewater Stabilization Ponds," Ecol.Modell., vol. 181, pp. 39-57, 2005.

[3] P. Hartati, "Studi Kinerja Boezem Morokrembangan Pada Penurunan KadarCOD, TS dan T SS Dalam Air Limbah Domestik Perkotaan," Makara, Sains, vol. 9, no. 2, pp. 45-51, 2012.

[4] S. Heaven, "A Review Of Harvesting of Micro-Algae for Bio fuel Production," Enviro Sci. Biotechnol, vol. 12, no. 165, 2013.

[5] J. Persson and H. Wittgren, "How Hydrological and Hydraulic Conditions Affect Performance of Ponds," Ecol. Eng., vol. 21, 2003.

[6] D. Wulandari, "Penanganan Sedimentasi Waduk Mrica," Ilm. Tek. Keair., vol. 13, no. 4, 2007.

[7] M. Moelyo, T. Januar, and P. Bambang, "Pengatuh Kualitas Sedimen Dasar Terhadap Karakteristik Lingkungan Keairan, St udi Kasus Saluran T arum Barat," J. Irig., vol. 7,no. 1, 2012.

[8] Satwika, "Teknis Penanganan Sedimen Secara Kuratifpada Bagian Selat an Boezem Morokrembangan," ITS, 2012.

[9] Hasriyani, "Studi Kinerja Boezem Morokrembangan pada Penurunan Kandungan Total Solid dan Zat Organik sebagai Permanganante Value (PV)," Surabaya, 2010.

[10] H. Rahman, "Aplikasi Program 'Water Balance Model' untuk Manajemen Air Hujan Perkotaan: Studi Kasus Pada Sub-DAS Sugutamu, Jawa Barat, Indonesia," 2008.

[11] D. Mara, Domestic Wastewater Treatment in Developing Countries. London: Earthscan, 2003.

[12] T. Septiana, "Studi Laju Akumulasi Lumpur pada Boezem Morokrambangan," Surabaya, 2011.

[13] Helfinalis, "Kandungan Total suspended solid dan Sedimen di Dasar Peraian Panimbang," 2005.
[14] V. Vanoni, “Sementation Engineering," Virginia, 2006

[15] B. Rumhayati, "Studi Senyawa Fosfat dalam Sedimen dan Air menggunakan Teknik Diffusive Gradient in Thin Films (DGT)," $J$. Ilmu Dasar, vol. 11, no. 2,2010.

[16] H. Efendi, Telaah Kualitas Air: Bagi Pengelolaan Sumber Daya dan Lingkungan Perairan. Yogyakarta: Kanisius, 2003.

[17] E. Pandebesie and W. Susi Agustina, "Inhibisi Nitrat Terhadap Pertumbuhan Algae Hijau (Chlorella sp)," J. Rekayasa Perencanaan, Fak. Tek. Sipildan Perenc.

[18] A. Retnosari, "Dekonsentrasi Amonium dan Nitrat oleh Ducweed," Surabaya, 1998.

[19] M. Ali, "Degradasi Nitrat Limbah Domistik Dengan Alga Hijau (Chlorella sp),"Surabaya, 2013.

[20] S. Roswaty, M. Muskananfola, and P. W. Purnomo, "Tingkat Sedimentasi di Muara Sungai Wedung Kecamatan Wedung, Demak," Diponegoro J. Maquares Manag. Aquat. Resour., vol. 2, no. 3, 2014

[21] R. D. Ratnani, I. Gartati, and L. Kurniasari, "Pemanfaatan Eceng Gondok (eichornia Crassipes) untuk Menurunkan Kandungan COD (Chemichal Oxygen Demand), pH, Bau, dan Warnapada Limbah Cair T ahu," Semarang, 2010.

[22] R. Gumilang, "Studi Penentuan Koefisien Biodegradasi Air Limbah Domestik Influen Boezem Morokrembangan," Surabaya, 2010.

[23] I. Hakim, "Pemanfaatan Eceng Gondok (Eicjornia Cassipes) sebagai Media Bioremediasi Terhadap Penurunan Kadar Total suspen ded solid(T SS)," Unnes J. Public Heal., 2012.

[24] L. Waluyo, Mikrobiologi Lingkungan. Malang: UMMPress, 2009.

[25] Kementrian Kelautan dan Perikanan, "Rekomendasi Teknologi Kelautan dan Perikanan,"2014.

[26] A. Utomo, "Merajut Hidup dari Bengok: Pola-Pola P emanf aatan Bengok (Eceng Gondok) di Sekitar Danau Rawa Pening dalam PrespektifPembangunan Berkelanjutan,"J. Cakrawala, 2017. 